\title{
NUCLEAR GEOSTRATEGY OF THE POST-COLD WAR ERA
}

\author{
Marius-Cristian NEACȘU, Ph.D., \\ Associate Professor, Bucharest University of Economic Studies, Romania. \\ E-mail: marius.neacsu@ase.ro \\ Silviu NEGUT, Ph.D., \\ Professor, Bucharest University of Economic Studies, Romania. \\ E-mail: silviu.negut@gmail.com
}

\begin{abstract}
The use of nuclear energy has changed the world's geopolitical and geostrategic landscape irreversibly, distinguishing another attribute of "high power", namely that of nuclear power, which not only means the possession of a nuclear arsenal, but also trade in civil nuclear technology (nuclear reactors for electricity generation) placing the selling state and the buyer in a geopolitical relationship. What's new? The emergence of a new nuclear military power, China, perceived as a "growing tiger", and new exporters of civil nuclear technology, Russia and China, which now concentrate 2/3 of reactor construction in the world after the long period of the Cold War when the global civilian nuclear energy market was dominated by the US.
\end{abstract}

Keywords: nuclear geopolitics; nuclear geostrategy; nuclear power; nuclear security.

\section{Introduction}

Context. The Cold War was defined, among other things, at geostrategic level, by a genuine "nuclear balance", also referred to as "terror balance" in terms of international order, and we start from this perspective that nuclear technology possession places you in a select and very narrow club of "nuclear powers", it is also one of the most representative attributes of great power. The exclusivity came from the huge capacity to destroy possessed by nuclear bombs in military terms and from their potential for being used for persuasion and deterrence in negotiations.

The end of the Cold War changed the perspective of the ideological order, but it did not consist of the disappearance of nuclear arsenals or the temptation to threaten with their use.

As a result, the aim of this study is to identify the changes that have occurred in the distribution of nuclear power and the "balance", from a geopolitical and geostrategic point of view, after the end of the Cold War. The emphasis of this research is given by the fact that the military dimension of nuclear technology is not the only one that has geopolitical significance, but also the civil dimension, the latter becoming preeminent in the post-Cold War power games.

\section{The geopolitical and geostrategic dimension of nuclear energy}

The use of nuclear energy has irreversibly changed the world's geopolitical and geostrategic stage, distinguishing another attribute of "great power" or "superpower", namely that of nuclear power. And nuclear power does not mean only the possession of a nuclear arsenal, but also the commercialization of civil nuclear technology (nuclear reactors for electricity generation) placing the selling state and the buyer in a geopolitical relationship (Yoshida 2020, 12). 
STRATEGIES XXI International Scientific Conference

The Complex and Dynamic Nature of the Security Environment

From this point of view, nuclear geostrategy has two dimensions:

a) military - the balance between nuclear powers (with their own arsenal, anti-missile shield, cyber and anti-satellite capabilities, etc.);

b) civil - the use of export of civil nuclear technology for geopolitical and geostrategic purposes.

In terms of the military dimension, the whole geopolitical equation of the Cold War was based on the nuclear balance (nuclear parity between the two superpowers, the US and the USSR), also known as the terror balance - the threat regarding the usage of nuclear weapons. The exact expression of the application of this balance on the ground, namely the perceived effects of the imbalance of the normal nuclear balance was the well-known "Cuban nuclear missile crisis" (1962), an episode we did not insist on (see Malița 2009, 382-403).

Additionally, the US is the only nuclear power that used the nuclear bomb in a real war (August 6th, 1945, launching the "Little boy" bomb in Hiroshima, and three days later on August 9th, "Fat Man" in Nagasaki - a nuclear attack that has led to the haste of the end of World War II, by taking Japan out of the game) and the first nuclear power to deliver civil nuclear technology and a market for peace-keeping since 1953 (The "Atoms for Peace" program).

As regards the military dimension, each US President has tried to change, to reform his predecessor's nuclear strategy, Paulsen (2014) summarizing all this doctrine development during the Cold War, as follows:

a) the containment strategy - specific to the starting point, when the United States were the planet's only nuclear power (1945-1953), initiated by President Harry Truman;

b) the massive retaliation strategy - was created during the Eisenhower administration, in the 50's, against the background of the emergence of the USSR as a nuclear player and the active conflicts in South Asia (Korean Peninsula); it was the period of the quantitative explosion, the US nuclear arsenal increasing from about 1,000 in 1953 to 18,000 nuclear warheads in 1960 (Paulsen 1994, 5);

c) the flexible response strategy depending on the context and situation - applied in the 60 's ("Kennedy moment" and the mandate of Lyndon Johnson);

d) the hard peace strategy, a kind of peacekeeping through the manifestation of power (peace through strenght), applied in the 80's (the "Reagan era"), during which another geostrategic doctrine was initiated, namely the Strategic Defence Initiative, presented in literature under the term "stars war" (the design of anti-missile shields);

e) the soft peace strategy, i.e. peace through denuclearisation or peace through disarmaments, at the end of the 80's and early 90's in the Bush Sr. - Gorbaciov tandem.

Since the USSR entered the nuclear power club, the Soviets had only one dominant doctrine, namely the equivalence of US nuclear power through the quantitative increase in nuclear arsenal ("catch-up-to-the Americans", see Paulsen 1994, 16).

The 90's were a hesitating period in terms of international order (Cold Peace) and the manifestation of the American hegemony, following the implosion of the ideological and strategic adversary (the disappearance of the USSR as an actor and the geopolitical withdrawal of Moscow), have brought the individualization of another nuclear doctrine based on deterrence (deterrence strategy), during Clinton administration (for more details see Leveringhaus 2018, 77-90; Müller and Schaper 2004).

The geostrategic logic of the nuclear field in the present has not changed much compared to the one during the Cold War era (see also Hall, Capello and Lambert 1998), but there are some nuances that need to be mentioned:

Firstly, quantitatively, nuclear arsenal has been reduced, but the technological evolution (hypersonic missiles, cyber-attacks, missile shields, and so on) can influence the balance, 
"altering" the classic Cold War model: "There are many more variables in the equation and future arms control negotiations will require the presence of the US, Russia, China to redesign the strategic stability" (Creedon et al. 2019, 4).

If, after the "missile crisis" in Cuba (1962), the United States, for example, had about it 30,000 nuclear warheads, in 2018, the total nuclear arsenal amounted to about 15,000 units, of which more than $90 \%$ was held by Russia and the USA (6,850 and 6,550 units respectively), the rest being dispersed in France (2\%, 300 units), followed by China (280 nuclear warheads), Great Britain (215), Pakistan (145), India (135), and between 1\% and 2\% each, less than one percentage being held by Israel ( 80 nuclear warheads) and North Korea with 15 nuclear warheads (Ibidem, 2). Close and somewhat more up-to-date values also provide other sources, with a relative decrease in US nuclear arsenal $(5,550)$ and slight increases in China (350), Pakistan (165), India (156), North Korea, with uncertain values at the latter level, even three times higher, i.e. 40-50 (SIPRI 2021).

Secondly, the emergence of a new nuclear military power, China, is perceived as "a growing tiger - To expect China not to use its muscles is like waiting for a tiger's baby not to grow its teeth" (Ibidem, 6) - or as "the biggest player in the history of mankind" (Allison 2017, p. VII).

Thirdly, the emergence of new exporters of civil nuclear technology, Russia and China, which currently own $2 / 3$ of reactor construction market around the world, after the global civil nuclear energy market was dominated by the US for a long time during the Cold War, with $41 \%$ of all reactors sold in the timeframe 1969-1990. After the end of the Cold War, between 1991 and 2017, it dropped to only $8 \%$ (Carless 2020, 19).

\section{The "new" nuclear powers}

Trade with nuclear materials and technologies is geopolitical by its nature (Nakano 2020, 3), each of the three first nuclear powers following another strategy:

a) the USA ("declining nuclear leader"), a business one;

b) Russia ("the new leader"), the largest supplier in the field (Szepers 2019, 1), a geostrategic one (Conca 2017); similar to the case of natural gas, the former Soviet-era Ministry of the Gas Industry became the state-owned Gazprom and the former Atomic Energy Ministry became Rosatom, both geostrategic instruments at the disposal of President Vladimir Putin, exporting technology for nuclear reactor construction in Belarus, India, Bangladesh, Turkey and Egypt;

c) China ("the next big leader"), a geo-economics one (increasing and expanding its economic power), building reactors in Pakistan, Uzbekistan, last together with Russia (Nakano 2020; de Blasio 2017, 15).

Therefore, at the moment, the US must share nuclear leadership with Russia and China, with the increase in competition over recent years being attributed to both Moscow and Beijing, both using trade in civil nuclear technology "to gain influence in regions of strategic value, especially Eastern Europe, South Asia and the Middle East" (Miller and Volpe 2018a). At least, in the last of the regions mentioned, Iran's nuclear ambitions have sparked a similar reaction from Saudi Arabia (Miller and Volpe 2018b, 27-46), with the kingdom under the US security umbrella becoming the target of the "geostrategic nuclear exports" (Hibbs 2017) of Russia and China.

In the same way, North Korea's unpredictability and aggressiveness regarding nuclear weapons - where nuclear power has this feature of being a tool almost exclusively used for the survival of the regime and also of the Kim dynasty (der Meer 2011), the frequency of the testing and the strength of the bombs being much higher during Kim Jong Un compared to his father 
STRATEGIES XXI International Scientific Conference

The Complex and Dynamic Nature of the Security Environment

Kim Jong Il - could end up putting Japan in front of the same solution, namely to have its own nuclear arsenal (McMaster 2020).

While US and China are suppliers of globalization, both of which need a peace-based international order, the latter still preserving the rhetoric of the "second hit", which is "we will not strike first" - a defensive rhetoric, coupled, paradoxically, with an increase in offensive capacity in cyberspace and anti-satellite (Creedon et al. 2019, 6), Russia does not participate in globalization, judging and playing geostrategically well in conflictual situations. At the same time, Russia and China are perceived as "revisionist powers" (Rudolf 2020) - China, as a "systemic rival" from the point of view of the European Commission (apud Cline et al. 2020, 25), seeking to change the international order in their own interest and building spheres of influence. A complicated geostrategic equation...

\section{Post-Cold War nuclear geostrategy elements}

In the area of nuclear geostrategy, Herbert Raymond McMaster, former national Security Adviser (2017-2018) during the Trump administration, denounces the "escalation control" doctrine (McMaster 2020), initiated by Vladimir Putin to intimidate NATO member states and weaken Alliance cohesion: the threat of early nuclear attacks in Europe with the aim of putting the US in the face of a strategic dilemma, namely the risk of a nuclear holocaust or the negotiation of peace on Russia-favourable terms. Basically, a continuation of the principles of the "first hit" and the "tertiary part" during the Cold War.

The emergence of China as a nuclear power was analysed in some studies from the perspective of the Thucydides trap: "The rise of Athens and the fear it has established in Sparta have led to the inevitable war" (Allison 2017, VII), which, translated in terms of today's nuclear geostrategy, would sound like: "China's nuclear rise and fear caused in the US could make the inevitable war" (see also Gaub 2020), and the author highlighted some common features at former US President Donald Trump and Xi Jinping (Allison 2017, VII):

Both have been led by the common ambition to make each one of their nations "great again": if about the failure of Donald Trump as a "leader of the free world" we are already aware, as the announced doctrine is well-known, "let's make America great again", XI Jinping's achievement remains to be seen: China as a superpower; it is known only the Chinese time horizon, i.e. 2049 (the year when the New Silk Road/Belt and Road Initiative is also estimated to be finished), the year of Mao Zedong/Tsedun Centenary.

Identifying the other players as obstacles to their dreams: let's remember the mutual attacks on the virus subject in 2020, at the start of the COVID-19 pandemic, of the two protagonists (Donald Trump and XI Jinping) or Trump's roads in North Korea, in an attempt, which has not been successful, to make Kim Jong UN abandon the development of its nuclear capabilities (plus their hilarious rhetoric on the nuclear "button").

The pride/ego as a dominance of their leadership capabilities, which, at least from this perspective, can be similar to the strategic-nuclear confrontation in 1962, during the "Cuban missile crisis" between Nikita Hrusciov and J.F. Kennedy.

Also, both have taken a central role in revitalizing their own nations, using words as "radical change" on the domestic policy agenda and both were perceived as the exponents of nationalist-populist visions, each of which was clinging its own historical mission.

Joe Biden's coming to the White House meant a return to the nuclear geostrategy of the Obama administration, a series of words such as "no first use", "in last resort" or "extreme circumstances" defining the political framework regarding the use of nuclear weapons (Xiaobing 2021), which describe a nuclear geostrategy of a soft deterrence strategy, rather than a hard deterrence strategy. 
The world is changing and the nuclear geostrategic equation is taking on as many variables as possible. For example, the United Arab Emirates is the first Arab state to operate a nuclear power plant (the Barakah nuclear power plant, currently unique in the whole Arab Peninsula, located close to the shore, in the south of the Persian Gulf, with 4 reactors already in operation, three in 2020 and the last one since 2021, with an installed capacity of $600 \mathrm{MW}$, covering $25 \%$ of national electricity consumption). And the United Arab Emirates have become the newest space actor, with the objective of achieving a human habitable colony on the planet Mars by 2117, a robotic space probe of its own, "Hope" ("Al-Amal"), already gravitating around the planet (arrived there on 9 February 2021).

\section{Conclusions}

The analysis of nuclear geostrategy in the post-Cold War period has led to a number of conclusions, as follows:

The cold War "cornerstone" was the nuclear balance. As one of the most relevant attributes of great power, nuclear weapon ownership had particular geostrategic significance during the Cold War, especially through the perspective of the strategic balance ("of terror", as it was called) which had to be maintained both in terms of quantity and quality of nuclear arsenal, and last but not least, through the number of nuclear powers in the world. The USSR's implosion and the end of the Cold War did not mean the disappearance of the nuclear threat or the disappearance of the nuclear weapons stocks owned by the great powers, but merely the reconfiguration of nuclear geostrategy.

In terms of nuclear geostrategy doctrines, of military origin, they have evolved from the offensive ones during the Cold War to the defensive ones of the present ("no first use"). Most of the American doctrines of the second half of the last century in the area of nuclear geostrategy were offensive, the massive retaliation strategy being just an example Currently, the deterrence strategy is the most used, which is true, has suffered a few nuances, from a "hard" version during the Trump administration to a "soft" one at present (which means, in fact, a return to the previous one during the Obama administration).

In the post-Cold War period, civil nuclear energy also took a geopolitical and geostrategic meanings. The possession of nuclear weapons, a characteristic of the Cold War, has been changed into a strategic field with the export of civil nuclear technology versus geopolitical dependence. There are two major exporters of civil nuclear technology at the moment, namely Russia and China, which together concentrate $2 / 3$ of the reactor construction around the world, replacing the US as the dominant supplier in the field before the fall of the Berlin Wall.

The views of the current nuclear powers are different. While the US, as a civilian nuclear power, is perceived as a declining leader with a business vision, Russia is considered a "new leader", which uses the export of civil nuclear technology as a geopolitical and geostrategic tool, while the emerging Chinese has a geoeconomical strategy.

\section{BIBLIOGRAPHY:}

GRAHAM Allison. 2017. Destined for War: Can America and China Escape Thucydides's Trap? Boston/New York: Houghton Mifflin Harcourt.

BLASIO, Nicola de and Richard NEPHEW. 2017. The Geopolitics of Nuclear Power and Technology. New York: Center on Global Energy Policy, Columbia University. URL: https://energypolicy.columbia 
STRATEGIES XXI International Scientific Conference

The Complex and Dynamic Nature of the Security Environment

edu/sites/default/files/The\%20Geopolitics\%20of\%20Nuclear\%20Power\%20and\%20Techn ology\%20033017.pdf

CARLESS, Travis. 2020. "The US Shouldn't Abandon the Nuclear Energy Market." Science and Technology 36, no. 2 (Winter): 19-22. URL: https://issues.org/wpcontent/uploads/2020/01/Carless-The-US-Shouldnt-Abandon-the-Nuclear-EnergyMarket-Winter-2020.pdf

CLINE, Mary K., MCCAFFREY, RICKERT Courtney, LAWLESS, Kyle P. and BEHRENDT Sven. 2020. 2020 Geostrategic Outlook: Global rebalancing raises uncertainty for business. A transformative age in geopolitics. London: Ernst \& Young Global Limited, Geostrategic Business Group. URL: https://assets.ey.com/content/dam/ey-sites/ey-com/en_gl/topics/ geostrategy/ey-gbg-2020-geostrategic-outlook.pdf?download

CONCA, James. 2017. "The Geopolitics of The Global Nuclear Landscape." Accessed October 8, 2021. URL: https://www.forbes.com/sites/jamesconca/2017/05/20/the-geopolitics-ofthe-global-nuclear-landscape/?sh=69e227c75f68

CREEDON, Madelyn, EINHORN, Robert, JENKINS, Bonnie, MALONEY, Suzanne, O'HANLON, Michael, Pak, JUNG, Rose, FRANK and Strobe TALBOTT. 2019. "Managing Risk: Nuclear Weapons in the New Geopolitics." Interview by Bruce Jones. Foreign Policy, February 11, 2019. Transcript. URL: https://www.brookings.edu/wpcontent/uploads/2019/02/FP_20190211_nonproliferation_interview.pdf

GAUB, Florence. 2020. Conflicts to come: 15 scenarios for 2030. Paris: European Union for Security Studies.

HALL, Gwendolyn M., CAPELLO, John T. and LAMBERT Stephen R. 1998. A Post-Cold War Nuclear Strategy Model. USAF Academy (Colorado): USAF Institute for National Security Studies. URL: https://www.hsdl.org/?view\&did=437817

HIBBS, Mark. 2017. "Does the U.S. Nuclear Industry Have a Future?.” Accessed October 8, 2021. URL: https://carnegieendowment.org/2017/08/10/does-u.s.-nuclear-industry-havefuture-pub-72797

LEVERINGHAUS, Nicola. 2018. "Beyond 'hangovers': The new parameters of post-Cold War nuclear strategy." In New Directions in Strategic Thinking 2.0, edited by Russell W. Glenn, 77-90. Canberra: Australian National University Press.

MALIȚA, Mircea. 2009. “Criza rachetelor: ONU, New York, 1962.” In Pagini din diplomația României, edited by Ion Anghel, Lucian Petrescu, Valeriu Tudor, 382-403. Iași: Editura Junimea.

MCMASTER, Herbert Raymond. 2020. Battlegrounds: The Fight to Defend the Free World. New York: HarperCollins.

MEER, Sico van der. 2011. "Geopolitics and Nuclear Weapons: North Korean Provocations as a Tool for Regime Survival.” Studia Diplomatica LXIV, no. 3: 53-65.

MILLER, Nicholas and Tristan VOLPE. 2018b. "Abstinence or Tolerance: Managing Nuclear Ambitions in Saudi Arabia." The Washington Quarterly 41, no. 2: 27-46.

MILLER, Nicholas and VOLPE Tristan. 2018a. "Geostrategic Nuclear Exports: The Competition for Influence in Saudi Arabia." Accessed October 8, 2021. URL: https://warontherocks.com/2018/02/geostrategic-nuclear-exports-competition-influencesaudi-arabia/

MÜLLER, Harald and SCHAPER, Annette. 2004. US Nuclear Policy after the Cold War. Translated by Catherine Mulder. Frankfurt: Peace Research Institute. 
NAKANO, Jane. 2020. The Changing Geopolitics of Nuclear Energy. A Look at the United States, Russia, and China. Washington D.C.: Center for Strategic \& International Studies. URL: $\quad$ https://csis-website-prod.s3.amazonaws.com/s3fs-public/publication/200416_ Nakano_NuclearEnergy_UPDATED\%20FINAL.pdf?heOTjmYgA_5HxCUbVIZ2P GedzzQNg24v

PAULSEN, Richard A. 1994. The role of US nuclear weapons in the post-Cold War era. Maxwell Air Force Base (Alabama, USA): Air University Press. URL: https://www.airuniversity.af.edu/Portals/10/AUPress/Books/b_0058_paulsen_role_ nuclear_weapons.pdf

RUDOLF, Peter. 2020. "U.S. Geopolitics and Nuclear Deterrence in the Era of Great Power Competitions." Political Science Quarterly 136, no. 1: 129-153. URL: https://doi.org/10.1002/polq.13132

SCHEPERS, Névine. 2019. "Russia's Nuclear Energy Exports: Status, Prospects and Implications." Non-Proliferation and Disarmament Papers, no. 61 (February): 1-14. URL: https://docs.google.com/viewerng/viewer?url=http://www.nonproliferation.eu/wpcontent/uploads/2019/03/ EUNPDC_no-61_FINAL.pdf\&hl=en

SIPRI. 2021. "Global nuclear arsenals grow as states continue to modernize-New SIPRI Yearbook out now." Accessed October 9, 2021. URL: https://sipri.org/media/pressrelease/2021/global-nuclear-arsenals-grow-states-continue-modernize-new-sipriyearbook-out-now

XIAOBING, Guo. 2021. "Biden can push through 'no first use' nuclear policy if sincere." Accessed October 9, 2021. URL: https://www.globaltimes.cn/page/ 202107/1228579.shtml

YOSHIDA, Phyllis Genther. 2020. Japan's Nuclear Reactor Fleet: The Geopolitical and Climate Implications of Accelerated Decommissioning. Washington D.C.: Global Energy Center, Atlantic Council. URL: https://www.atlanticcouncil.org/wp-content/uploads/ 2020/12/AC_Japan_FINAL.pdf 